\section{CANADA}

\section{Call for policy reform}

The Canadian Association of University Teachers (CAUT) in Ottawa wants the government to provide more federal funds for basic research, restore the role of independent national science officer and reduce restrictions on scientists' interactions with media and the public (see Nature 483, 6; 2012). In its Get Science Right campaign, launched on 25 April, the CAUT aims to promote transparency in research and support of basic science through its website and public discussions about federal policy. James Turk, executive director of the CAUT, which represents 68,000 academic faculty members, researchers and staff, argues that the government is focusing on business innovation at the expense of basic research. "Changes must be made," he says.

\section{UNITED STATES}

\section{Health-coverage clarity}

US lawmakers should clarify how the health-care legislation known as Obamacare applies to adjunct faculty members, says a higher-education union. The law - parts of which are slated for adoption by 2014 - could be a boon to adjuncts, many of whom do not currently have health insurance. Under the rules, anyone working at least 30 hours per week would qualify for coverage. But universities have said that it will be difficult to quantify workloads by the hour. "We're very concerned about transparency," says Craig Smith, director of higher education for the American Federation of Teachers in Washington DC. He adds that the law should require that adjuncts help institutions to calculate their work hours.

\section{EUROPEAN UNION}

\section{Mobility initiatives}

A university coalition is proposing schemes to expand student mobility. In International Curricula and Student Mobility, out on 25 April, the League of European Research Universities in Leuven, Belgium, argues for networked mobility - in which one university sets up student exchanges with others - and embedded mobility, in which several universities create a curriculum and exchange students and teachers. Each would involve more students than Erasmus, the existing European exchange programme, says Bart De Moor, vice-rector of international policy at the Catholic University of Leuven and co-author of the report.

To begin with, you simply want someone in the know to tell you the truth. You read textbooks and attend lectures, and are overawed by the immensity of it all but struck by how neatly everything fits together. You do a few simple experiments in your lab, and you get exactly the results that are expected. There seem to be answers to all of your questions, and you feel that if you read enough textbooks and attend enough lectures then you will understand all there is to understand. This is the stage I was at when I finished my first undergraduate degree, and what I was expecting to find when I went back to do my master's.

\title{
CONFLICTING STORIES
}

The second stage begins when you realize that scientists frequently disagree with each other about what is true. This stage is disturbing, and is caused by taking the business of writing essays and papers seriously. Typically, you will be given a question along the lines of, "What function does Broca's area of the brain serve?" To answer it, you start by reading a long paper by Professor X, who sets out his theory in convincing detail. You think, "Of course, how obvious. It controls the processing of syntax how could anyone think otherwise?" Next, you read an equally long and detailed review

\section{"If I am lucky, I will spend the rest of my life finding new things that I will never quite be able to explain."} paper by Professor Y, who takes a contrary view, and you think, "Hmm. Professor Y makes some very good points. Perhaps Professor X doesn't know what he's talking about after all". And then on you go to Professor Z, and utter confusion. One of them must be telling the truth, but which one? So you write your essay, describing the contrasting theories of $\mathrm{X}, \mathrm{Y}$ and $\mathrm{Z}$ and conclude: "Opinion is divided - more research is necessary." This is the stage I was at when I finished my master's degree. I decided that maybe I could do some of that research, so I started a $\mathrm{PhD}$.

The third stage of becoming a scientist begins with the realization that nobody knows the truth. This stage is absolutely terrifying, and is caused by doing research. When I started running real experiments, collecting data and testing my ideas against those data, I came to realize that things were not as clear cut as they had seemed from the papers that I had been reading. Sometimes things did not work out as predicted by any of the theories that I knew about. There was always something that could not be explained. I found this troubling, and began to doubt my work. Luckily, I had a very supportive supervisor.
When you start doing science at the $\mathrm{PhD}$ level, you begin to work and socialize with real scientists - occasionally the very scientists who wrote the papers that so impressed you during your studies. Once you become a professional scientist, these people are usually happy to let you in on an important trade secret: nobody is really sure of anything. A scientific paper is just one cut and polished facet of a bigger, uglier stone. Behind the beautiful graphs and whip-smart arguments lies a tangled mass of doubts, conjectures and anomalies. Pulling any loose thread is usually enough to make the paper lose its shape. The most important thing my supervisor taught me was that this is not a bad thing.

\section{BETTER AND BETTER}

Some scientists are lucky enough to pass through a fourth stage. This is when you realize that science is not about finding the truth at all, but about finding better ways of being wrong. The best scientific theory is not the one that reveals the truth - that is impossible. It is the one that explains what we already know about the world in the simplest way possible, and that makes useful predictions about the future. When I accepted that I would always be wrong, and that my favourite theories are inevitably destined to be replaced by other, better, theories - that is when I really knew that I wanted to be a scientist.

A theory can never be perfect: the best it can be is better than the theory that went before. I want to come up with better theories about how the brain works. If I can do this, then someone else can use my ideas to come up with something even better. As theories improve, we are able to make more useful predictions about how things might work in the real world, and from those predictions we can develop better treatments. I want to be part of this progression. This means that, if I am lucky, I will spend the rest of my life finding new things that I will never quite be able to explain.

So there it is. My interest in the brain is pragmatic, rather than curious. I never really wanted to become a scientist. But I became one eventually, because I had to.

Thomas M. Schofield was a postdoctoral fellow in neuroscience at New York University. He died in 2010 in a bus accident in Colombia. Writer Stephen S. Hall helped to edit this essay on his behalf.

\section{CORRECTION}

The Careers Feature 'Artistic merit' (Nature 496, 537-539; 2013) wrongly named the Scientists/Artists Research Collaborations as an initiative of the Santa Fe Institute instead of the 1st-Mile Institute in Santa Fe. 